\title{
Pyroglutamate Aminopeptidase I Promotes Hepatocellular Carcinoma via IL6/STAT3 Activation as Revealed by a Specific Biosensor
}

Wu-Yingzheng Guo, ${ }^{1,}$ Rong-Rong Li ${ }^{1,}{ }^{1}$ Yi-Xuan Fu, ${ }^{1}$ Shi-Yu Liu, ${ }^{1}$ Guo-Zhen Liu, ${ }^{1}$ Wen-Chao Yang, ${ }^{1, *}$ and Guang-Fu Yang ${ }^{1}$

${ }^{1}$ Key Laboratory of Pesticide \& Chemical Biology of Ministry of Education, International Joint Research Center for Intelligent Biosensor Technology and Health, College of Chemistry, Central China Normal University, Wuhan 430079, P.R. China

\section{Table of contents}

1. Experimental section $\cdots \cdots \ldots \ldots \ldots \ldots \ldots \ldots \ldots \ldots \ldots \ldots \ldots \ldots \ldots \ldots, \mathrm{S} 2-\mathrm{S} 3$

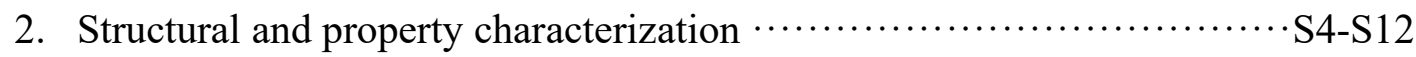

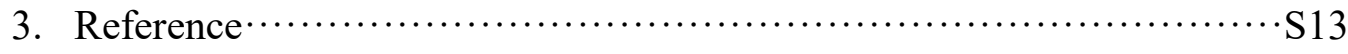

${ }^{\S}$ These two authors made equal contributions.

*Wen-Chao Yang, Tel: 86-27-67867706; Fax: 86-27-67867141; E-mail:

tomyang@mail.ccnu.edu.cn. 


\section{Experimental section}

\section{Synthesis methods and structural characterization}

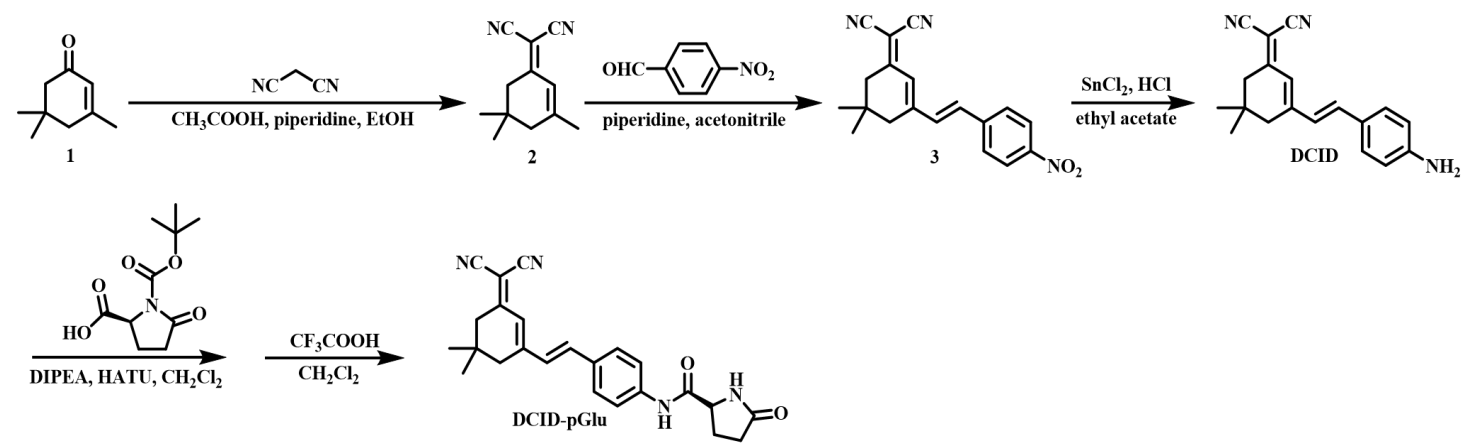

Figure S1. Synthesis of the target probe DCID-pGlu.

The synthesis of the intermediates $\mathbf{2}$ and $\mathbf{3}$ was carried out according to previous literature(Cheng et al., 2019). Next, the intermediate 3 (3.19 g, $10 \mathrm{mmol}$ ) and $\mathrm{SnCl}_{2} \cdot 2 \mathrm{H}_{2} \mathrm{O}(2.26 \mathrm{~g}, 10 \mathrm{mmol})$ were dissolved in ethyl acetate $(50 \mathrm{~mL})$, followed by the dropwise addition of hydrochloric acid $(1 \mathrm{~mL})$. Subsequently, the reaction mixture was heated up and refluxed for $8 \mathrm{~h}$. After the reaction completed, the reaction solution was washed with distilled water $(4 \times 70 \mathrm{~mL})$. Ethyl acetate layer was reserved and concentrated by rotary evaporator. Finally, the condensed mixture was further purified by the Flash column chromatography (petroleum ether/ethyl acetate, 5:1) to afford compound DCID as red powder (2.08 g, 71.9\%). ${ }^{1} \mathrm{H}$ NMR (400 MHz, DMSO-d 6 ) $\delta 7.41(\mathrm{~d}, J=8.4 \mathrm{~Hz}, 2 \mathrm{H}), 7.17(\mathrm{~d}, J=16.0 \mathrm{~Hz}$, 1H), $7.04(\mathrm{~d}, J=16.0 \mathrm{~Hz}, 1 \mathrm{H}), 6.70(\mathrm{~s}, 1 \mathrm{H}), 6.56(\mathrm{~d}, J=8.4 \mathrm{~Hz}, 2 \mathrm{H}), 5.88(\mathrm{~s}, 2 \mathrm{H})$, $2.56(\mathrm{~s}, 2 \mathrm{H}), 2.50(\mathrm{~s}, 2 \mathrm{H}), 1.00(\mathrm{~s}, 6 \mathrm{H}) \cdot{ }^{13} \mathrm{C}$ NMR (100 MHz, DMSO) $\delta$ 170.3, $158.0,151.8,140.3,130.6,123.9,123.9,120.4,115.0,114.3,114.2,73.2,42.8$, 
38.7, 32.1, 27.9. HRMS (MALDI): calcd for $\mathrm{C}_{19} \mathrm{H}_{19} \mathrm{~N}_{3}[\mathrm{M}+\mathrm{H}]^{+}$290.1651, found: 290.1650.

Thereafter, (S)-boc-5-oxopyrrolidine-2-carboxylic acid (344 mg, $1 \mathrm{mmol}$ ) was dissolved in $\mathrm{CH}_{2} \mathrm{Cl}_{2}(20 \mathrm{~mL})$, followed by the addition of DIPEA (261 $\mathrm{mg}$, $1.5 \mathrm{mmol})$ and HATU (570 $\mathrm{mg}, 1.5 \mathrm{mmol})$. The resultant mixture was stirred at room temperature for $24 \mathrm{~h}$. Later, DCID (289 $\mathrm{mg}, 1 \mathrm{mmol}$ ) was added in the reaction mixture and was further stirred at room temperature for $24 \mathrm{~h}$. After the reaction was completed, the mixture was washed with water and the organic layer was concentrated in vacuum. Then, the crude product was dissolved in DCM (10 $\mathrm{mL}$ ) and $7 \mathrm{~mL} \mathrm{CF}_{3} \mathrm{COOH}$ was added. After $20 \mathrm{~min}$, the reaction was quenched by $20 \mathrm{~mL}$ ice water, and extracted by DCM. The organic layer was concentrated under reduced pressure, and further purified by flash column chromatography on silica gel to get the 54 mg of (R, E)-N-(4-(2-(3-(dicyanomethylene)-5,5-dimethylcyclohex-1-en-1-yl) vinyl) phenyl)-5-oxopyrrolidine-2-carboxamide (named as DCID-pGlu) as the final product (in $11 \%$ yield). ${ }^{1} \mathrm{H}$ NMR (400 MHz, DMSO- $\left.d_{6}\right) \delta 10.24(\mathrm{~s}, 1 \mathrm{H}), 7.90$ (s, 1H), $7.76-7.61(\mathrm{~m}, 4 \mathrm{H}), 7.33(\mathrm{~d}, J=16.4 \mathrm{~Hz}, 1 \mathrm{H}), 7.24(\mathrm{~d}, J=16.0 \mathrm{~Hz}, 1 \mathrm{H})$, $6.85(\mathrm{~s}, 1 \mathrm{H}), 2.53(\mathrm{~s}, 2 \mathrm{H}), 2.50(\mathrm{~s}, 2 \mathrm{H}), 2.42-2.29(\mathrm{~m}, 1 \mathrm{H}), 2.27-2.09(\mathrm{~m}, 2 \mathrm{H})$, $2.06-1.94(\mathrm{~m}, 1 \mathrm{H}), 1.01(\mathrm{~s}, 6 \mathrm{H}) .{ }^{13} \mathrm{C}$ NMR (100 MHz, DMSO) $\delta$ 177.9, 172.0, $170.7,156.6,140.6,137.7,131.7,129.1,128.7,122.8,119.9,114.4,113.6,76.3$, 56.9, 42.8, 38.7, 32.1, 29.7, 29.1, 27.9, 25.8. HRMS (MALDI): calcd. for $\mathrm{C}_{24} \mathrm{H}_{24} \mathrm{~N}_{4} \mathrm{O}_{2}[\mathrm{M}+\mathrm{Na}]^{+}$423.1792, found: 423.1811 . 
2. Structural and property characterization

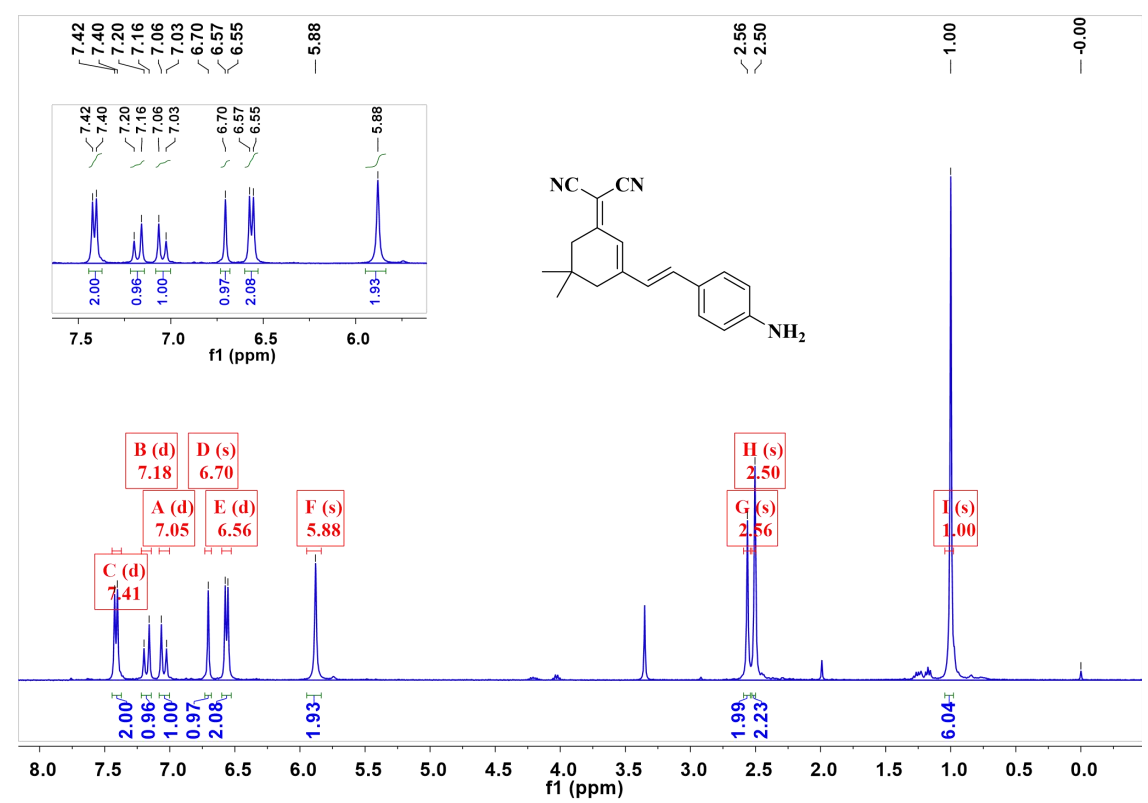

Figure S2. The ${ }^{1} \mathrm{H}$ NMR spectrum of the DCID. (400 MHz, DMSO- $d_{6}$ ). 


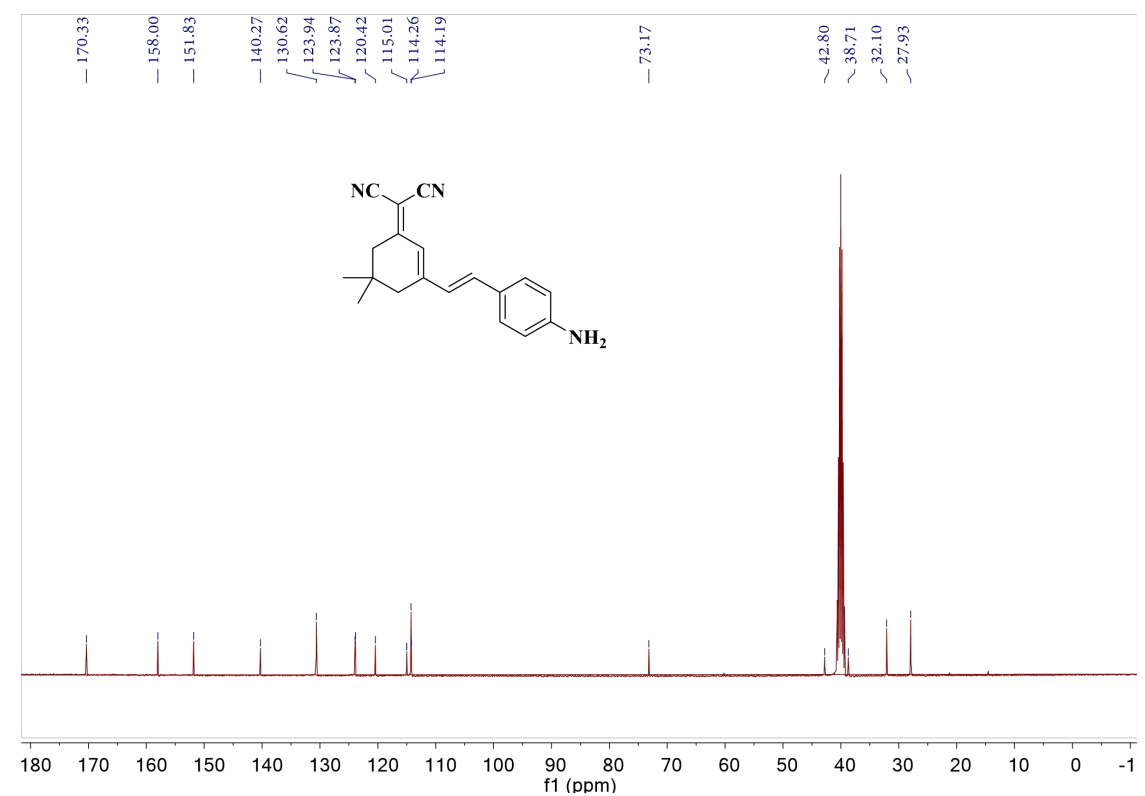

Figure S3. The ${ }^{13} \mathrm{C}$ NMR spectrum of the DCID. (100 MHz, DMSO- $\left.d_{6}\right)$.

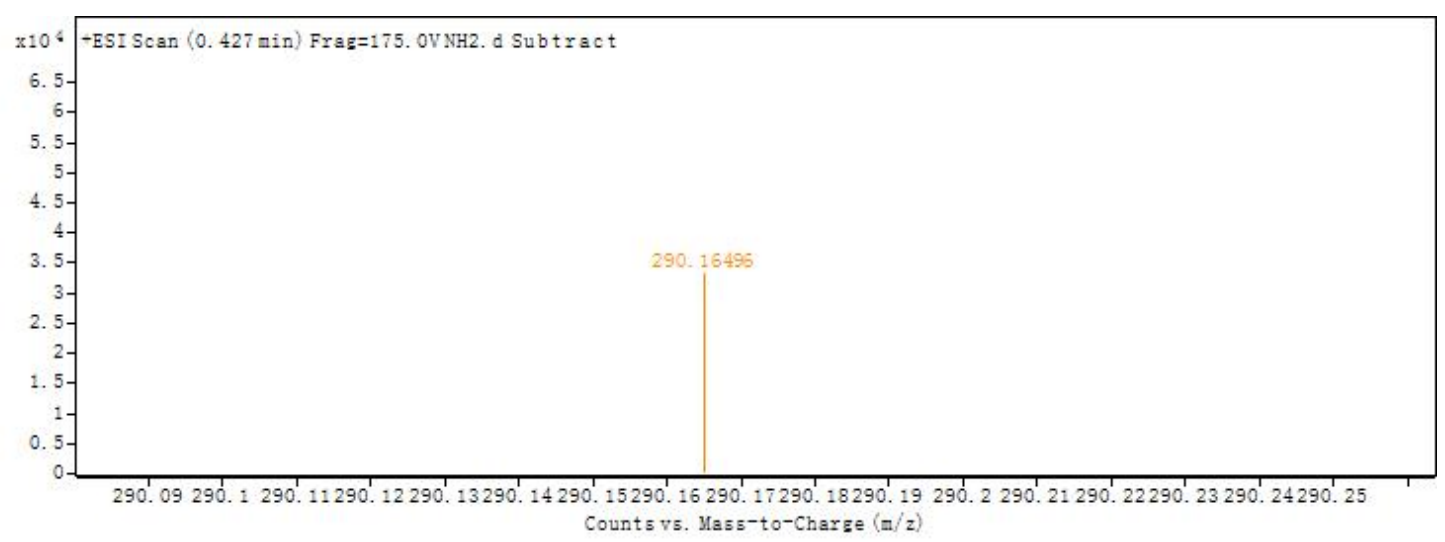

Figure S4. ESI mass spectrum of DCID. 


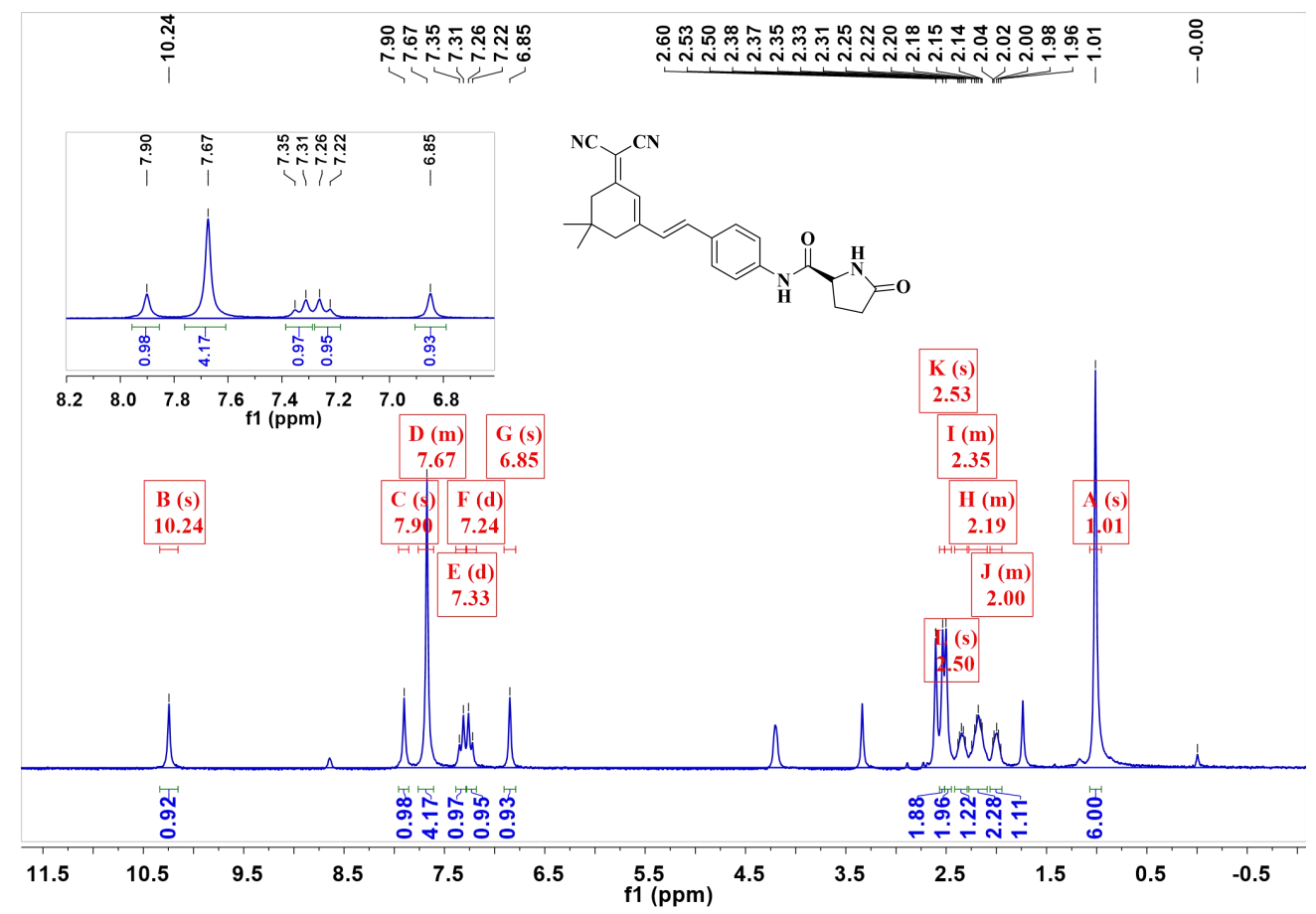

Figure S5. The ${ }^{1} \mathrm{H}$ NMR spectrum of DCID-pGlu (400 $\mathrm{MHz}, \mathrm{CDCl}_{3}$ ).

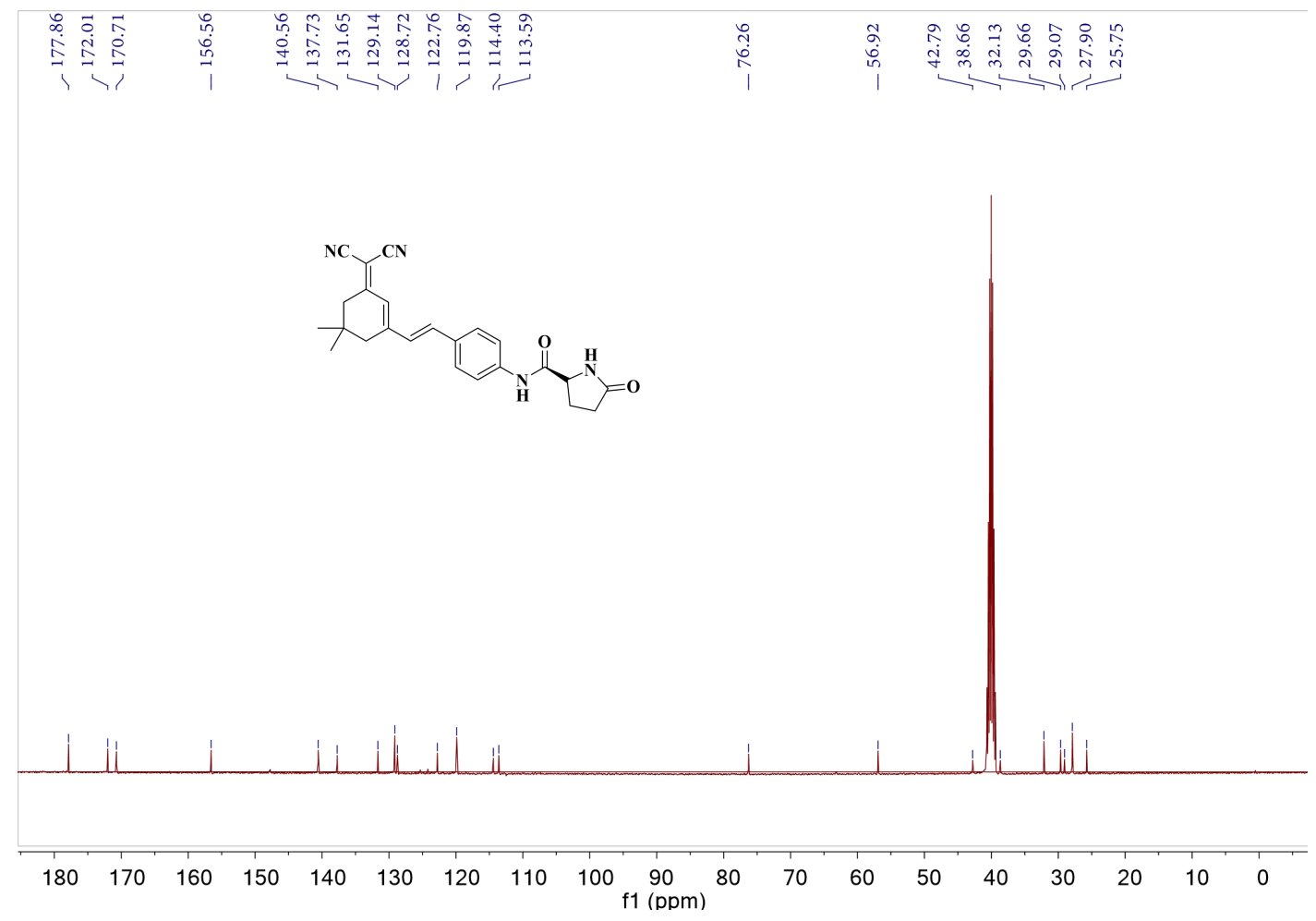

Figure S6. The ${ }^{13} \mathrm{C}$ NMR spectrum of the DCID-pGlu (100 MHz, DMSO- $\left.d_{6}\right)$. 


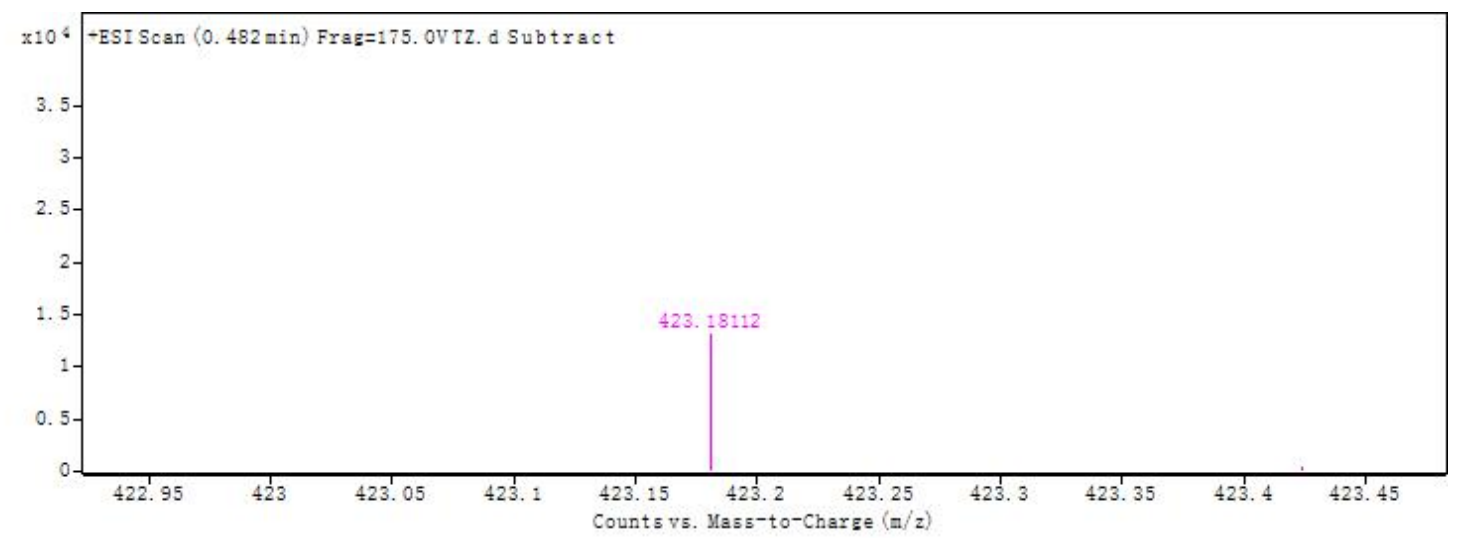

Figure S7. ESI mass spectrum of DCID-pGlu.

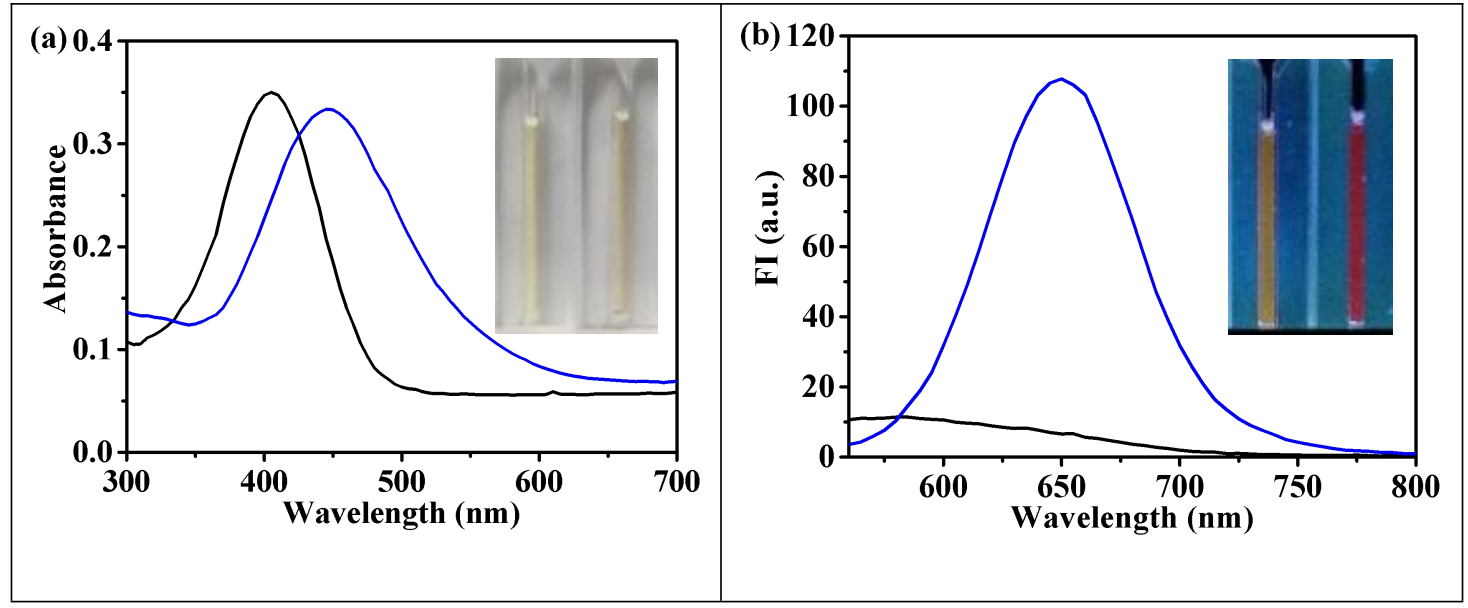

Figure S8. Absorption (a) and fluorescence (b, $\lambda_{\text {ex/em }}=450 / 650 \mathrm{~nm}$ ) spectra of DCID-pGlu $(10 \mu \mathrm{M})$ before (black line) and after (blue line) reaction with PGP-I $(0.2$ $\mu \mathrm{g} / \mathrm{mL})$ at $37^{\circ} \mathrm{C}$ for $40 \mathrm{~min}$ in PBS buffer $(\mathrm{pH}=7.4)$. The inset in (a) shows the photo of the corresponding reaction mixture in the absence (left) and presence (right) of PGP-I $(0.2 \mu \mathrm{g} / \mathrm{mL})$ at $37{ }^{\circ} \mathrm{C}$ for $40 \mathrm{~min}$ in PBS buffer $(\mathrm{pH}=7.4)$. The inset in (b) shows the photo of the corresponding reaction mixture in the absence (left) and presence (right) of PGP-I $(0.2 \mu \mathrm{g} / \mathrm{mL})$ under UV light at $365 \mathrm{~nm}$ at same condition. 


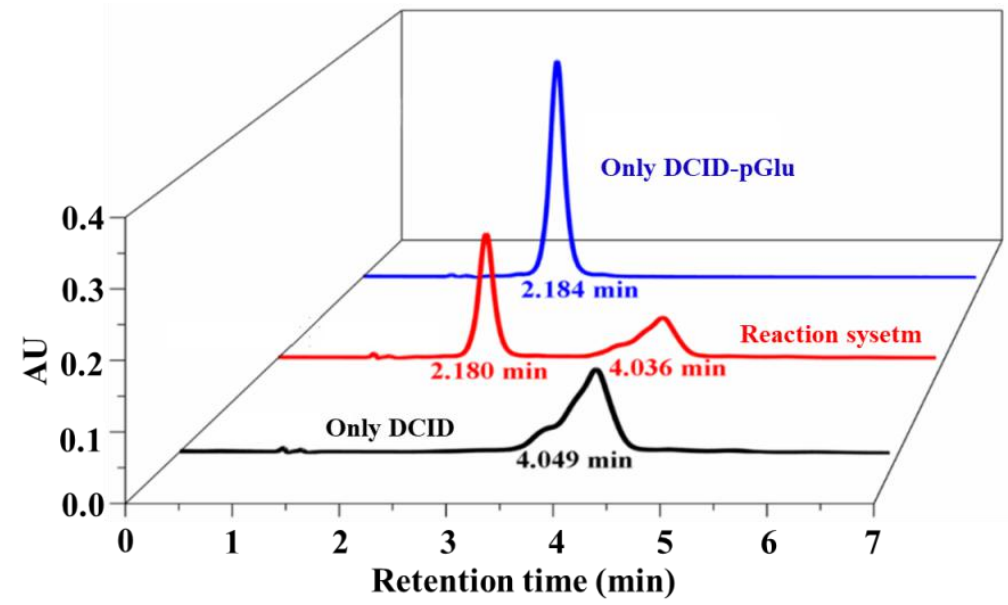

Figure S9. HPLC spectrum of the DCID-pGlu $(40 \mu \mathrm{M})$ with (red curve) and without (black curve) the addition of PGP-I $(20 \mu \mathrm{g} / \mathrm{mL})$ incubated for $1 \mathrm{~h}$ in PBS buffer $(10 \mathrm{mM}, \mathrm{pH}=7.4)$ at $37^{\circ} \mathrm{C}$. The fluorophore DCID (blue curve) was used as control.

(a)

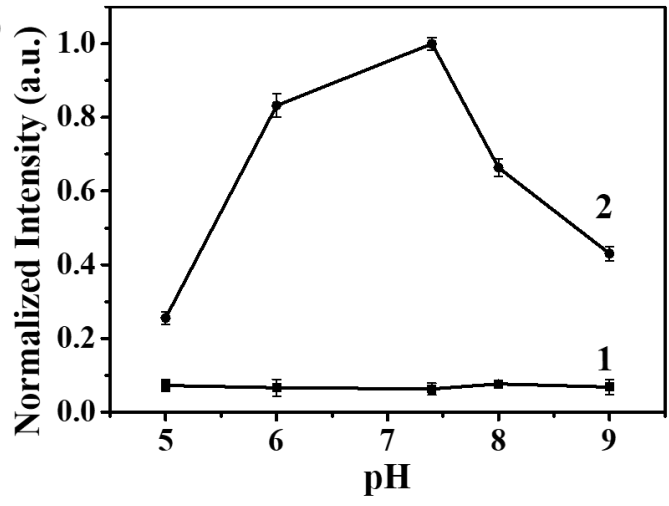

(b)

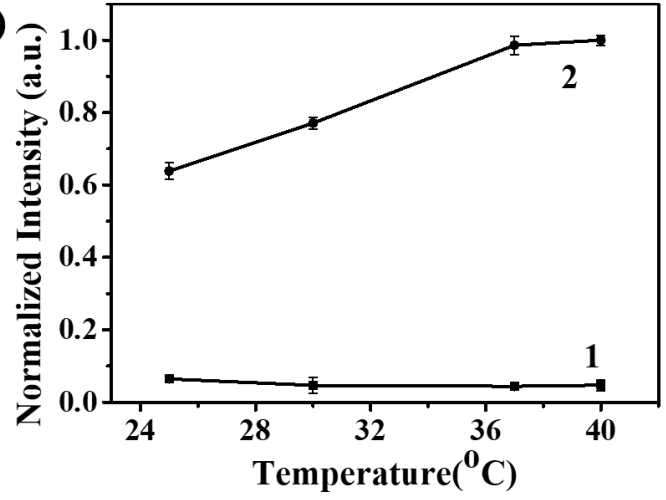

Figure S10. Effects of $\mathrm{pH}$ (a) and temperature (b) on the fluorescence of $10 \mu \mathrm{M}$ DCID-pGlu in the absence (1) and in the present (2) of PGP-I $(0.2 \mu \mathrm{g} / \mathrm{mL})$. Assay conditions: (a) the reaction system was performed in $10 \mathrm{mM}$ PBS for 40 min at different $\mathrm{pH}$ values which was adjusted with diluted $\mathrm{HCl}$ or $\mathrm{NaOH}$; (b) the reaction system was performed in $10 \mathrm{mM}$ PBS $(\mathrm{pH}=7.4)$ for $30 \mathrm{~min}$ at different temperatures. $\lambda_{\mathrm{ex} / \mathrm{em}}=450 / 650 \mathrm{~nm}$. 
(a)

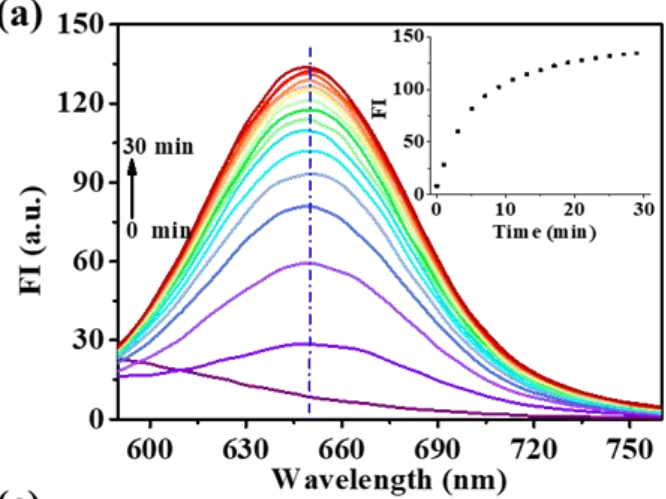

(c)

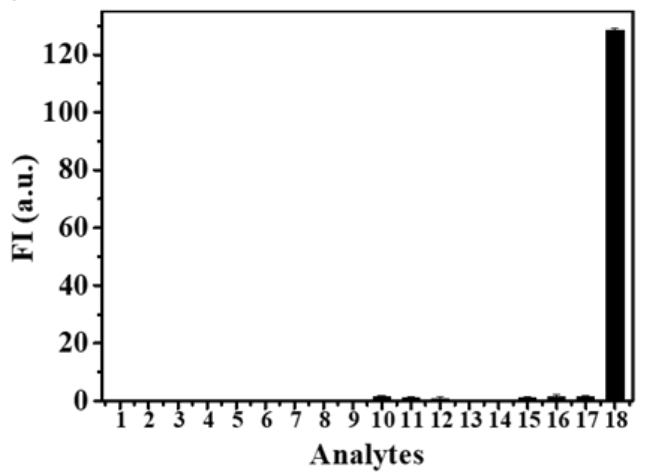

(b)

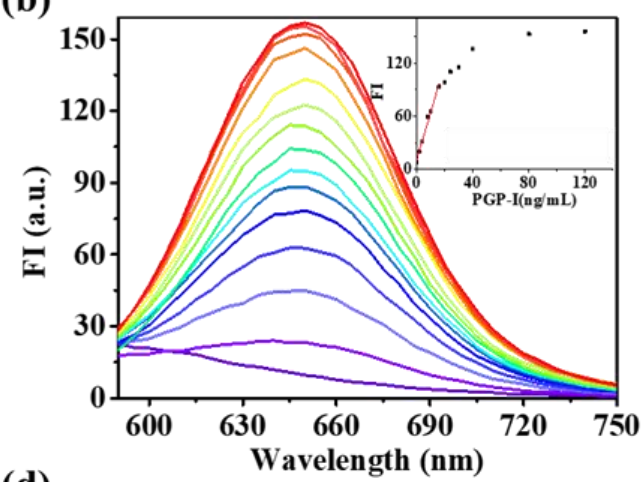

(d)

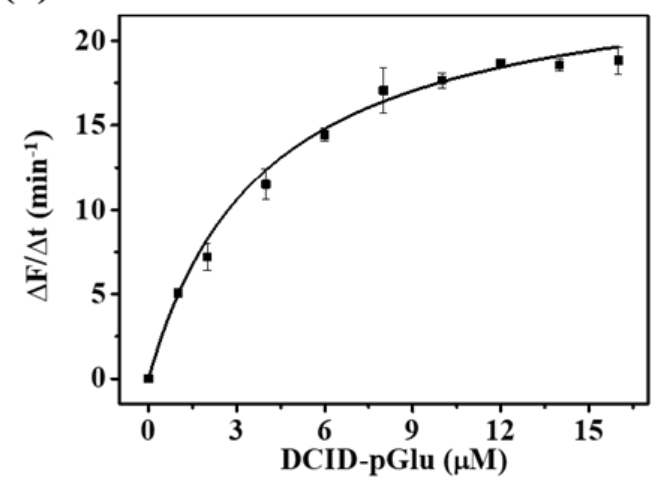

Figure S11. (a) Time dependent fluorescence spectroscopy of DCID-pGlu (10 $\mu \mathrm{M})$ incubation with PGP-I $(0.2 \mu \mathrm{g} / \mathrm{mL})$. (b) The fluorescence spectra of DCID-pGlu with the increasing concentrations of PGP-I. (c) Fluorescence response of DCID-pGlu $(10 \mu \mathrm{M})$ in the present of various potential interfering species $(10 \mu \mathrm{g} / \mathrm{mL}$ except notation). 1. Control, 2. AChE, 3. BChE, 4. Trypsin, 5. CTR, 6. ACP, 7. Glut, 8. CPB, 9. PLE, 10. GSH (40 $\mu \mathrm{M})$, 11. Asp (40 $\mu \mathrm{M}), 12$. Ser $(40 \mu \mathrm{M})$, 13. Cys $(40 \mu \mathrm{M}), 14$. LAP $(10 \mu \mathrm{g} / \mathrm{mL}), 15$. APN $(10 \mu \mathrm{g} / \mathrm{mL}), 16$. FAP $(10 \mu \mathrm{g} / \mathrm{mL}), 17$. DPPIV $(10 \mu \mathrm{g} / \mathrm{mL}), 18$. PGP-I $(0.2 \mu \mathrm{g} / \mathrm{mL})$, Reaction time: 30 min. (d) The kinetic curve for the fluorescence changes of DCID-pGlu (0-20 $\mu \mathrm{M})$ catalyzed by PGP-I. All measurements were performed in aqueous solution $(10 \mathrm{mM}$ PBS, $\mathrm{pH}=7.4)$ at $37^{\circ} \mathrm{C}$, and $\lambda_{\text {ex } / \mathrm{em}}=450 / 650 \mathrm{~nm}$. 


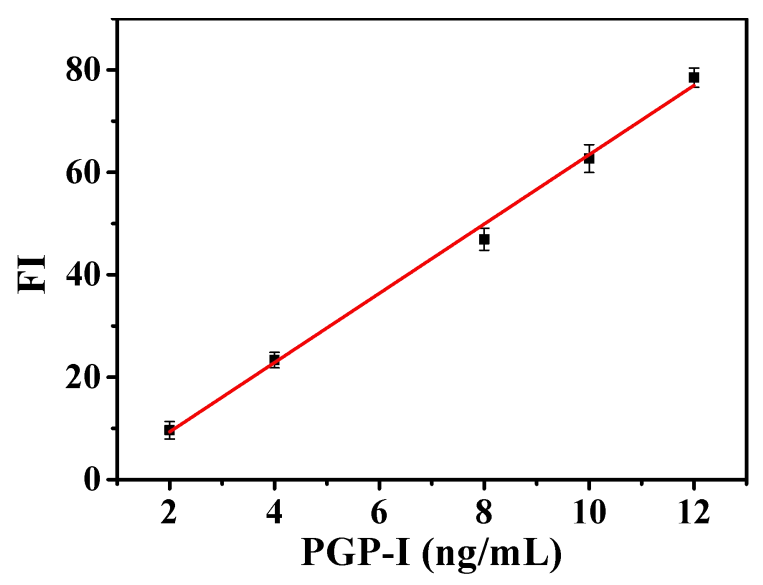

Figure S12. A plot of fluorescence enhancement of DCID-pGlu $(10 \mu \mathrm{M})$ against various concentration of PGP-I. The reaction was conducted at $37{ }^{\circ} \mathrm{C}$ in $10 \mathrm{mM}$ PBS (pH 7.4) for $30 \mathrm{~min}$. $\lambda_{\mathrm{ex} / \mathrm{em}}=450 / 650 \mathrm{~nm}$. The detection limit of DCID-pGlu was determined to be $3.1 \mathrm{ng} / \mathrm{mL}$.
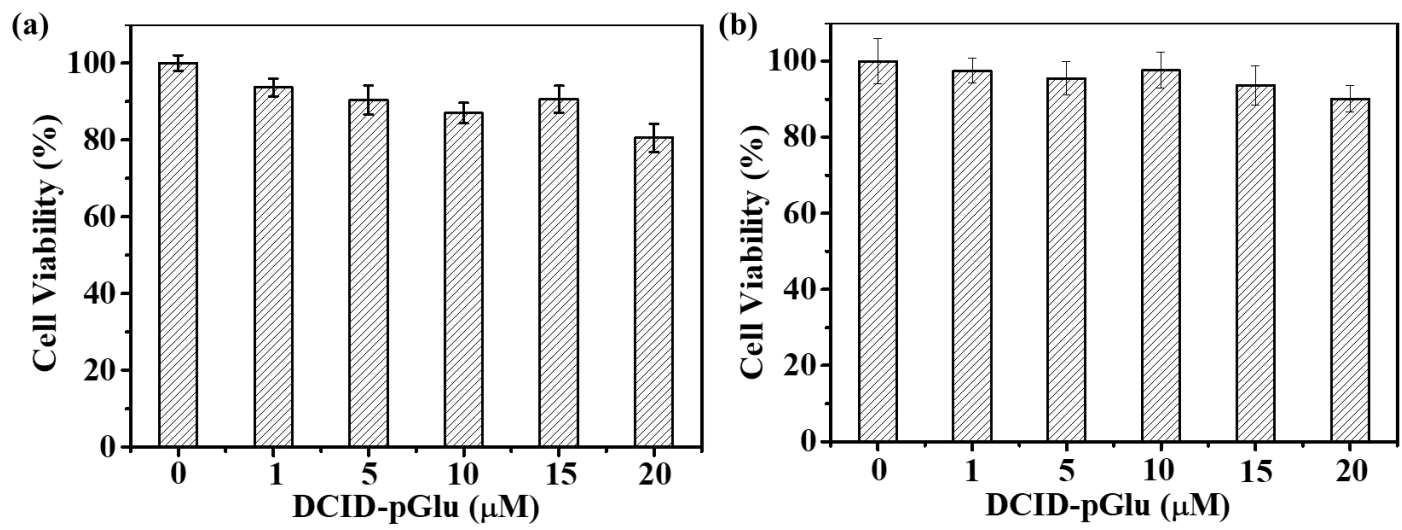

Figure S13. Effects of DCID-pGlu at varied concentrations $(0-20 \mu \mathrm{M})$ on the viability of (a) HepG2 cells and (b) LO2 cells for $24 \mathrm{~h}$ co-incubation. The viability of cells without DCID-pGlu is defined as $100 \%$. The results are the mean \pm standard deviation of five separate measurements. The result shows that DCID-pGlu have excellent biocompatibility to cells no matter normal cells or cancer cell. 
Table S1. Comparison of the fluorescent probes for PGP-I detection.

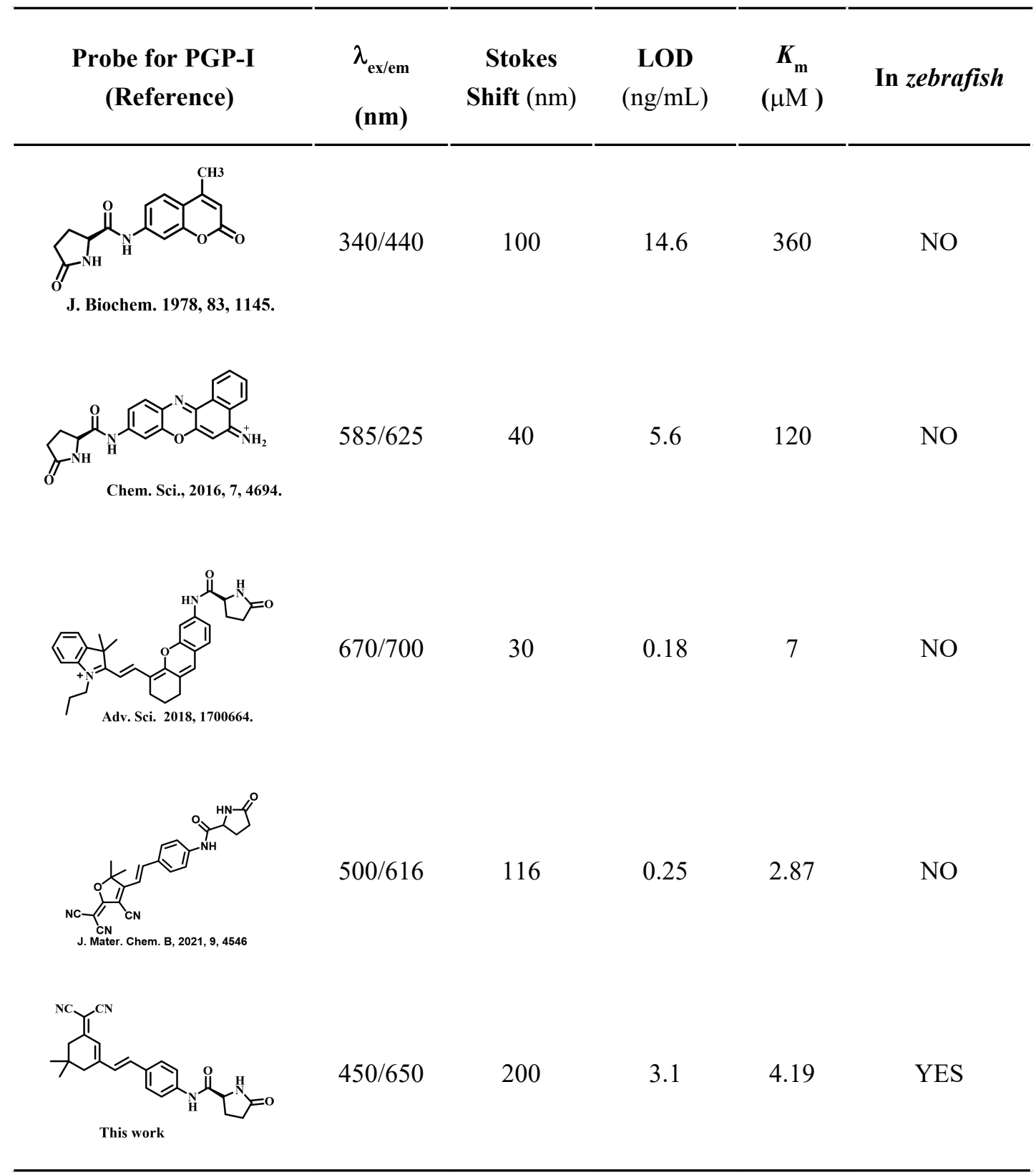



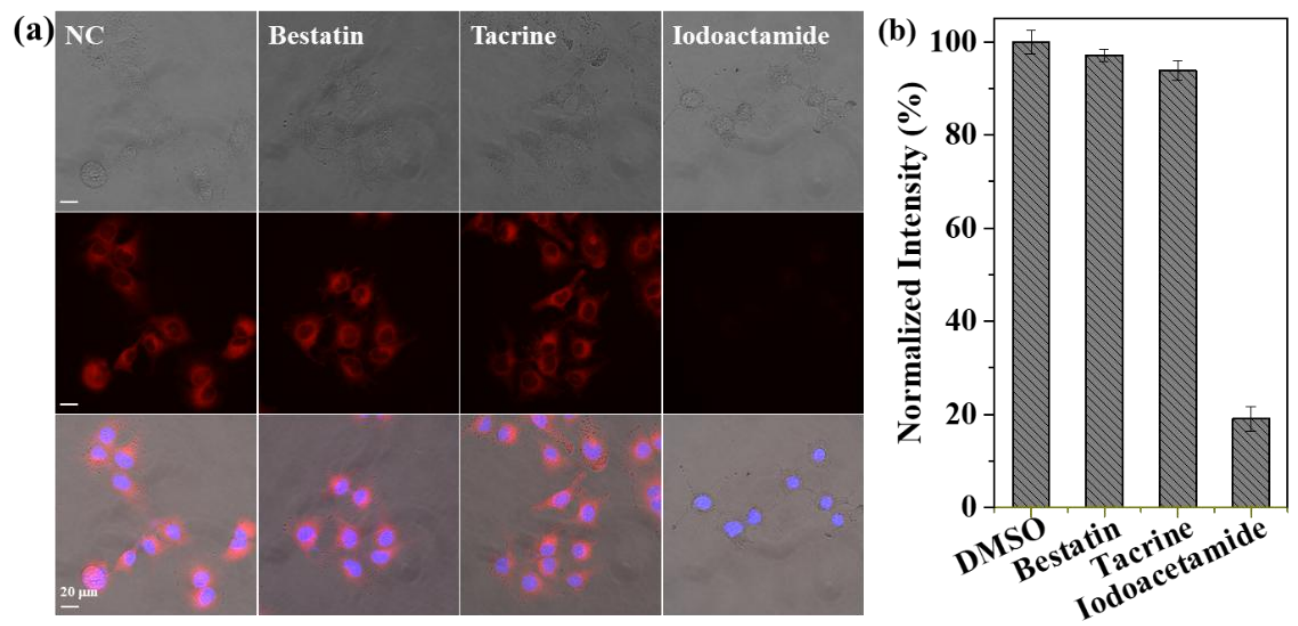

Figure S14. (a) Fluorescence images of HuH-7 cell pre-incubated with different inhibitors including Bestatin $(100 \mu \mathrm{M})$, Tacrine $(100 \mu \mathrm{M})$, and Iodoacetamide (4 $\mu \mathrm{M})$ with $4 \mathrm{~h}$, then incubated with DCID-pGlu $(5 \mu \mathrm{M})$ for $50 \mathrm{~min}$. (b) Relative pixel intensity of the correspond fluorescence images in panel a (the pixel intensity from image of control cells treated with DMSO is defined as 1.0). The results are the mean \pm standard deviation of three separate measurements.

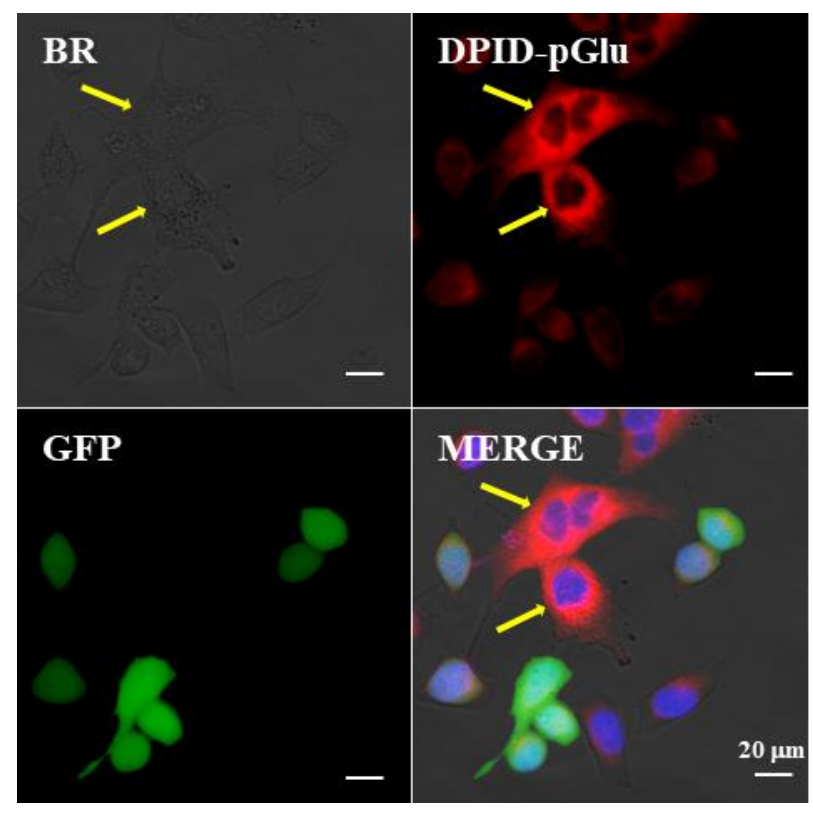

Figure S15. Fluorescence images of the cell mixture $(\mathrm{HuH}-7$ cells and GFP-transfected LO2 cells) treated with DCID-pGlu, the yellow arrows indicate the $\mathrm{HuH}-7$ cells. 


\section{Reference}

Cheng, Y., Ma, F., Gu, X., Liu, Z., Zhang, X., Xue, T., Zheng, Y., Qi, Z., 2019. Spectrochim. Acta - Part A Mol. Biomol. Spectrosc. 210, 281-288. https://doi.org/10.1016/j.saa.2018.11.030 